\title{
(De)Legitimasi Hukuman Pidana Mati: Sebuah Pertimbangan Etis
}

\author{
Sonny Eli Zaluchu ${ }^{1}$, Eirene Kardiani Gulo ${ }^{2}$ \\ ${ }^{1}$ Sekolah Tinggi Teologia Baptis Indonesia (STBI) Semarang, Jawa Tengah, Indonesia \\ ${ }^{2}$ Sekolah Tinggi Teologi BNKP Sundermann Nias, sumatera Utara, Indonesia \\ ${ }^{1}$ sonnyzaluchu@stbi.ac.id, 2eirenegulo@sttsundermann.ac.id
}

\begin{tabular}{l} 
Article History \\
Received: \\
1 June 2019 \\
Revised: \\
10 June 2019 \\
Accepted: \\
13 June 2019 \\
\hline \\
Keywords \\
(Kata kunci): \\
biblical perpectives; \\
death penalty; \\
law; right to live; \\
hak hidup; \\
hukum; \\
hukuman mati; \\
perspektif alkitabiah
\end{tabular}

perspektif alkitabiah

\begin{abstract}
The death penalty is always in controversy. Ethical considerations in terms of ethics, principle, and criminality always produce two strong opinions, which are the pros and cons. The two opposing views have strong arguments and considerations concerning the maximum punishment for particular crimes. Countries in the world divided into two acts. Some chose the moratorium option, but there were also those who continued to defend it. This article describes that there are indeed substantive difficulties in an attempt to legitimize or delegitimize the death penalty. These difficulties are presented and analyzed in this paper by using theological approaches, especially in a legal perspective, the right to human life and biblical orders not to kill. The descriptive analysis was carried out by utilizing a literature review and research results.
\end{abstract}

\begin{abstract}
Abstrak
Hukuman mati selalu di dalam kontroversi. Pertimbangan moral dalam hal etika, azasi dan pidana selalu menghasilkan dua kubu pendapat yang sama-sama kuat yakni yang pro dan kontra. Kedua pandangan yang saling bertolak belakang tersebut memiliki argumentasi dan pertimbangan yang kuat menyangkut hukuman maksimal terhadap kejahatan istimewa. Negara-negara di dunia terbagi dua. Ada yang memilih opsi moratorium tetapi ada juga yang terus mempertahankannya. Artikel ini memaparkan secara deskriptif bahwa memang terdapat kesulitan-kesulitan substantif dalam setiap usaha legitimasi dan atau delegitimasi terhadap hukuman mati. Kesulitan-kesulitan tersebut dipaparkan dan dianalisis di dalam paper ini dengan menggunakan pendekatan teologis khususnya dalam persepektif hukum, hak hidup manusia dan perintah Alkitab untuk jangan membunuh. Analisis dilakukan secara dengan memanfaatkan tinjauan literatur dan hasil-hasil penelitian.
\end{abstract}

\section{Pendahuluan}

Data termutakhir di situs Amnesty Internasional tentang hukuman mati adalah tahun 2017. Di sana dilaporkan oleh Amnesty International bahwa di tahun tersebut, berlangsung eksekusi mati di 23 negara dengan jumlah eksekusi resmi 993. Ada kemungkinan jumlah ini lebih dari yang dilaporkan seiring kebijakan tertutup beberapa 
negara yang enggan melaporkan eksekusi mati terpidana. Walaupun angka itu turun $4 \%$ dibanding laporan tahun 2016 (1.032 eksekusi) dan turun 39\% dibandingkan jumlah eksekusi di tahun 2015, pelaksanaan hukuman mati masih menjadi tren beberapa negara di dunia. Situs yang sama juga melaporkan bahwa negara-negara yang melakukan itu antara lain China, Iran, Saudi Arabia, Iraq and Pakistan. ${ }^{1}$

Pada pihak lain, tidak semua negara menyetujui hukuman mati terhadap terpidana. Beberapa negara yang kontra terhadap hukuman mati, berhasil mempengaruhi PBB untuk mengeluarkan resolusi tidka mengikat agar negara-negara anggota badan dunia itu melakukan moratorium terhadap hukuman mati dinegaranya masing-masing. ${ }^{2}$ Akan tetapi hal tersebut tidak mengubah fakta negara-negara yang pro hukuman mati untuk tetap melakukan eksekusi terpidana mati di wilayahnya masing-masing. Indonesia termasuk di dalam negara yang hingga kini masih menyetujui adanya hukuman mati. Pelaksanaan hukuman mati terakhir dilaporkan berlangsung tahun 2015 silam. $^{3}$

Penelitian yang dilakukan oleh Rachman menyebutkan bahwa pro-kontra hukuman mati menjadi sebuah persoalan global, antara kelompok yang menghendaki agar diterapkannya hukuman mati terhadap pelaku kejahatan dengan tindak pidana terberat seperti korupsi, terorisme, pemberontakan dan pembunuhan terencana dan narkotika, dengan kelompok yang menentang pelaksanaan hukuman mati karena bertentangan dengan Pancasila dan UUD serta HAM dalam hal ini hak manusia untuk hidup (the right to life). ${ }^{4}$ Pro-kontra tersebut tidak pernah menemukan kata sepakat di dalam setiap forum dialog untuk mencapai titik temu, khususnya dilihat dari pendekatan hukum dan HAM. Sutoyo tidak secara tegas memberikan jawaban dan hanya memaparkan sikap yang berkembang ditengah masyarakat soal hukuman mati itu sendiri, ketika menulis di dalam papernya tentang hukuman mati kepada pelaku tindak pidana korupsi di Indonesia. ${ }^{5}$ Untuk itu, diperlukan kajian khusus di dalam bingkai teologis tentang problematika pelaksanaan pidana mati tersebut, kemana arah dukungannya, apakah kepada kelompok yang pro hukuman mati atau membela yang kontra? Ataukah terdapat

\footnotetext{
${ }^{1}$ Amnesty International, "Death Penalty,” Amnesty International, 2017, https://www.amnesty.org/en/what-we-do/death-penalty/; Dylan Aprialdo Rachman, "Secara Global, Tren Eksekusi Mati Tahun 2017 Mengalami Penurunan Artikel Ini Telah Tayang Di Kompas.Com Dengan Judul ‘Secara Global, Tren Eksekusi Mati Tahun 2017 Mengalami Penurunan', Https://Nasional.Kompas.Com/Read/2018/04/13/08033781/Secara-Global-Tre,” Kompas.com, 2018, https://nasional.kompas.com/read/2018/04/13/08033781/secara-global-tren-eksekusi-mati-tahun-2017mengalami-penurunan.

${ }^{2}$ Maria Donatelli, “117 Countries Vote for a Global Moratorium on Executions," World Coalition Against the Death Penalty, 2014, http://www.worldcoalition.org/united-nations-resolution-moratoriumdeath-penalty-executions-general-assembly.html.

${ }^{3}$ Erasmus A.T. Napitupulu, "Gambaran Umum Penjatuhan Pidana Mati Di Indonesia," Institue for Criminal Justice Reform, 2015, http://hukumanmati.web.id/category/data/.

${ }^{4}$ Adri Noor Rachman, "Hukuman Mati Di Indonesia (Death Penalty In Indonesia)," SSRN, 2014, https://doi.org/10.2139/ssrn.2407875.

${ }^{5}$ Daniel Sutoyo, “Tinjauan Teologis Terhadap Wacana Penerapan Hukuman Mati Bagi Pelaku Tindak Pidana Korupsi Di Indonesia," DUNAMIS: Jurnal Teologi Dan Pendidikan Kristiani 3, no. 2 (2019): 171, https://doi.org/10.30648/dun.v3i2.195.
} 
pertimbangan-pertimbangan substantif lainnya. Untuk menjawab persoalan tersebut tulisan ini dibuat.

\section{Metode}

Analisis dilakukan dengan tinjauan literatur. Pertama-tama dipaparkan perspektif hukum positif tentang hukuman mati dan dilanjutkan dengan terminologi HAM mengenai hak hidup. Hal ini dilakukan untuk memberi gambaraan mengapa hingga saat ini belum tercapai titik temu antara dua kelompok, pendukung dan penentang hukuman mati. Analisis dilengkapi dengan persepektif biblikal dengan memakai pendekatan PL maupun PB sehingga dapat diperoleh penjelasan teologis sekitar problematika ini. Sumber-sumber primer dari analisis adalah data adalah paper, laporan lembaga yang berkompeten, dan hasil-hasil penelitian yang dilaporkan secara resmi. Tulisan ini diharapkan memberikan uraian dan sebab-sebab kontroversial sehingga muncul dikotomi pro-kontra terhadap pidana mati itu sendiri.

\section{Pembahasan}

\section{Perspektif Hukum}

Domain utama dari hukuman mati adalah penegakan hukum. Tindakan hukum terberat itu dilakukan kepada pelaku pidana yang melakukan kejahatan sangat besar atau kadang disebut kejahatan denan pemberatan dan kejahatan luar biasa. Tauhid mengatakan bahwa hukuman mati dalam hukum positif diberikan bagi kejahatan kejahatan yang sifatnya memberatkan. Termasuk di dalamnya kejahatan terhadap kemanusiaan dan negara (terorisme, pemberontakan) serta pidana khusus lainnya seperti korupsi dan narkotika. ${ }^{6}$

Maksud dari pemberian hukuman ini ada dua. Pertama, sebagai hukuman setimpal atas kesalahan atau pelanggaran atau kejahatan yang dilakukan. Dan kedua, sebagai efek jera sehingga orang lain tidak mengikuti atau melakukan kejahatan serupa di masa yang akan datang. Contohnya di Tiongkok. Penelitian yang dikerjakan oleh Lu dan Zhang untuk memberikan perspektif ilmiah bagi pelaksanaan hukuman mati di negara Tirai Bambu itu. ${ }^{7}$ Kedua peneliti menemukan bahwa hukuman mati di sana merupakan warisan legal dari masa kerajaan hingga pemerintahan modern. Pelaksanaan eksekusinya berlangsung di muka publik, dan dulu dilakukan dalam bentuk pencekikan, pemenggalan kepala, atau pemotongan tubuh. Eksekusi modern sudah tidak seperti dulu lagi. Tetapi, efek publisitas tetap dipertahankan. Hal itu dimaksudkan untuk membentuk atmosfir kepatuhan masyarakat terhadap hukum dan pemerintah. Hukuman mati merupakan pesan penguasa kepada masyakarat untuk tidak melakukan kejahatan sebagaimana diatur di dalam undang-undang.

\footnotetext{
${ }^{6}$ Akhmad Zainut Tauhid, "Hukuman Mati Terhadap Pelaku Tindak Pidana Terorisme Perspektif Fikih Jinayah,” IN RIGHT Jurnal Agama Dan Hak Azazi Manusia 1, no. 2 (2012): 368.

${ }^{7}$ Hong Lu and Lening Zhang, "Death Penalty in China: The Law and the Practice," Journal of Criminal Justice, 2005, https://doi.org/10.1016/j.jcrimjus.2005.04.006.
} 
Hukuman mati sebagai bagian dari kultur legal juga terlihat di dalam sistem hukum beberapa negara Arab. Kasus-kasus TKI di Arab yang berakhir pada hukuman mati atas pelanggaran hukum menjadi indikator untuk menilai bahwa kejahatan yang besar selalu diberi hukuman setimpal dengan hukuman yang berat. Studi yang dilakukan oleh Insani memperlihatkan upaya pemerintah Indonesia yang memperjuangkan pembebasan warga negaranya dari tuntutan hukuman mati di Arab Saudi akibat tuduhan melakukan kejahatan berat. Beberapa diantaranya berupa tuduhan penyiksaan, melakukan pembunuhan, praktek sihir dan tertangkap karena perzinahan. ${ }^{8}$

Di Indonesia sendiri, KUHAP sebagai acuan di dalam penegakan hukum dan sistem peradilan, memberikan ruang bagi pidana mati terhadap pelaku kejahatan sebagai sebuah saksi pidana pokok. Terlihat di dalam pasal 10 KUHPidana yang mengatur jenis-jenis sanksi pidana dimana salah satunya adalah hukuman mati. Kemudian dapat ditemukan juga di dalam pasal 340 KUHPidana, yaitu sanksi pidana mati bagi pelaku tentang pembunuhan berencana. Berbagai produk UU juga mengatur hal yang sama. UU Nomor 35 Tahun 2009 tentang Narkotika, misalnya, mengatur pidana mati di dalam pasal 118 dan Pasal 121 ayat (2). Meskipun ada beberapa upaya untuk menghapuskan pidana mati di dalam sistem hukum, pemerintah Indonesia hingga saat ini, tetap mencantumkan pidana itu di dalam upaya penegakan hukum dan keadilan.

Dapat disimpulkan bahwa pidana mati dilihat dari sisi hukum positif, adalah sebuah sanksi yang memang telah diatur di dalam UU dan sistem hukum di dalam negaranegara yang masih menerapkannya. Selama negara-negara itu belum melakukan moratorium dan meratifikasi produk hukumnya, pidana mati tetap memiliki legalitas. Legalitas ini memberi payung bagi kelompok yang oleh Geisler disebut rekonstruksionisme dan retribusionisme. Kedua kelompok ini sama-sama memegang azas legalitas pidana mati tetapi berbeda di dalam pendefinisian. Rekonstruksionisme memberlakukan hukuman mati tanpa pandang bulu terhadap semua perilaku kejahatan yang serius. Sedangkan retribusionisme hanya mengijinkan hukuman mati secara terbatas, pada tindak kejahatan yang sifatnya luar biasa (extra ordinary). ${ }^{9}$

\section{Permasalahan dengan Hak Hidup}

Persoalan utama tentang pidana mati adalah jawaban atas pertanyaan siapa yang lebih berhak memutuskan kehidupan seseorang. Manusia (dalam hal isi sistem hukum, hakim, jaksa) atau Tuhan. Berkaitan dengan hak hidup yang dimiliki oleh setiap manusia, pidana mati selalu menyisakan persoalan. Hak tersebut melekat secara azasi sejak manusia lahir di bumi dan diakui secara universal. Tidak ada falsafah negara manapun di dunia ini yang menentang hak hidup itu dan menganut sistem bunuhmembunuh sebagai dasar penegakan hukum dan kehidupan sosial-bernegara. Itu

${ }^{8}$ Fitri Insani, "Upaya Indonesai Membebaskan Tenaga Kerja Indonesia Terpidana Hukuman Mati Di Arab Saudi," Jurnal Online Mahasiswa (JOM) Bidang Ilmu Sosial Dan Ilmu Politik 2, no. 1 (2014): 113, https://jom.unri.ac.id/index.php/JOMFSIP/article/view/3802/3693.

${ }^{9}$ Norman L. Geisler, Etika Kristen: Pilihan Dan Isu [Christian Ethics: Options and Issues], 5th ed. (Malang: SAAT, 2007), 246. 
sebabnya, berdasarkan pandangan ini, hukuman mati dianggap bertentangan dengan hak hidup setiap manusia. Hal ini terjadi karena kematian yang dialami seseorang terjadi karena kehidupannya diambil dengan sengaja oleh negara. ${ }^{10}$

Amnesty Internasional selaku lembaga yang aktif memperjuangkan penolakan hukuman mati di dunia, mengemukakan bahwa hukuman mati menjadi persoalan serius karena jenis hukuman ini melibatkan nyawa manusia. Mengingat sistem hukum yang tidak sempurna, dapat saja terjadi di dalam proses hukum yang mengarah pada pidana mati, kesalahan prosedural dan pengabaian hak-hak terpidana. ${ }^{11}$ Ketimpangan dan ketidaksempurnaan lembaga peradilan, dimulai dari penyidikan, penuntutan hingga vonis, tetap memberi peluang bagi pengambilan keputusan yang salah. ${ }^{12}$ Bahkan telah menjadi pengetahuan publik, di beberapa negara yang eskalasi kekuasaan politiknya sangat dinamis, hukuman mati justru dipergunakan sebagai alat diskriminasi dan kepentingan penguasa terhadap warga negara atas nama stabilitas dan keamanan dalam negeri. Dengan kata lain, mengambil nyawa manusia dengan sengaja, melalui cara yang salah dan prosedur yang tidak semestinya, telah menambah bobot kesalahan dari pidana mati itu sendiri. Menghukum pembunuh dengan membunuh hanyalah persoalan perbedaan legalitas. Pelaku kejahatan mengambil hak hidup orang lain melalui aksi kriminal, sementara penegak hukum mengambil hak hidup pelaku kejahatan dengan legitimasi hukum.

Meskipun di dalam legalitas hukum, tindakan mengambil nyawa orang lain digolongkan sebagai sebuah tindakan yang kejam oleh kelompok ketiga yang disebut Geisler sebagai kubu rehabilitasionisme. ${ }^{13}$ Kelompok ini memegang teguh pendirian bahwa tidak boleh terjadi hukuman mati atas kejahatan apapun. Salah satu pertimbangan etisnya adalah hak hidup manusia merupakan hak prerogatif Tuhan semesta alam. Manusia tidak memiliki legalitas ilahi untuk menyambil nyawa sesamanya apapun alasannya, baik melalui tindakan kriminal maupun secara legal. Atas pertimbangan inilah, walaupun belum berani mengambil keputusan radikal, seiring perubahan pola pikir, peningkatan kesadaran akan hak-hak asasi, perubahan sosial dan politik serta penataan sistem hukum, beberapa pemeritahan di dunia mulai terlihat membatasi dengan sangat ketat bahkan menghapus eksekusi mati di dalam sistem hukum dan peradilannya. Terlihat juga di dalam pelaksanaan eksekusi dengan cara tembak, para prajurit tidak pernah mengetahui, senjata siapa yang mengeluarkan peluru panas dan menewaskan terpidana mati. Hal tersebut dilakukan untuk mengurangi beban

\footnotetext{
${ }^{10}$ Benjamin Fleury-Steiner and Ross Kleinstuber, "Death Penalty," in International Encyclopedia of the Social \& Behavioral Sciences: Second Edition, 2015, https://doi.org/10.1016/B978-0-08-0970868.86020-1.

${ }^{11}$ Devina Halim, “5 Alasan Menolak Hukuman Mati Menurut Amnesty International Indonesia," Kompas.com, 2018, https://nasional.kompas.com/read/2018/10/10/23301511/5-alasan-menolakhukuman-mati-menurut-amnesty-international-indonesia.

${ }^{12}$ Atet Sumanto, "Kontradiksi Hukuman Mati Di Indonesia Dipandang Dari Aspek Hak Asasi Manusia, Agama Dan Para Ahli Hukum,” Perspektif 9, no. 3 (2004): 192-215, http://jurnalperspektif.org/index.php/perspektif/article/view/347.

${ }^{13}$ Geisler, Etika Kristen: Pilihan Dan Isu [Christian Ethics: Options and Issues], 246.
} 
moral eksekutor. Artinya, sistem hukum itu sendiri sadar dan memberi ruang bagi eksistensi moral dan etika di dalam pelaksanaan eksekusi. ${ }^{14}$ Walaupun menjadi penganjur hukuman mati, argumentasi Kania patut dipertimbangkan. Dikatakannya, pelaku eksekusi pidana mati sesungguhnya tidak dapat dihalangi oleh pertimbangan etis. Sebab eksekusi dapat dipertahankan melalui sebuah kerangka kerja etis yang sudah mapan dan menjadi bagian dari standar baku prosedural. ${ }^{15}$

Kerangka Declaration of Human Right sebetulnya sudah memberikan wawasan dan pengertian yang cukup untuk mengkritisi praktek pidana mati bagi pelaku kejahatan. Article 5 dari United Nations Universal Declaration of Human Right menegaskan bahwa tidak seorang pun boleh mengalami penyiksaan atau mengalami perlakuan atau hukuman yang kejam, yang tidak manusiawi atau merendahkan martabat manusia. ${ }^{16}$ Terlepas dari tindakan dan kualitas kejahatan yang pernah dilakukannya, seorang penjahat sekalipun, menurut deklarasi ini tidak patut diperlakukan secara tidak adil dan tidak manusiawi termasuk di dalam menjalankan hukuman yang diterimanya. Bagian ini menjadi sebuah entry point yang melihat pidana mati sebagai sebuah hukuman kejam dan tidak manusiawi.

\section{Perintah Jangan Membunuh}

Meskipun secara tegas, terdapat perintah tertinggi untuk 'jangan membunuh' (Kel. 20:13) di dalam Perjanjian Lama (PL), praktik pidana mati pada satu sisi terlihat di dalam sejumlah narasi PL. Ada dua kasus yang dapat menjadi bahan analisis.

Pembunuhan pertama di muka bumi yang dilakukan Kain kepada Habel, dapat menjadi bahan studi. Pada waktu itu, masyarakat belum berkembang dibandingkan masa suku-suku Israel di Kanaan. Kejahatan yang Kain lakukan itu termasuk pembunuhan berencana sehingga jika diukur dalam sistem hukum dewasa ini, Kain menghadapi ancaman pidana mati. Akan tetapi, Tuhan tidak menghukum mati Kain kecuali mengutuk dan mengusirnya. Keberlangsungan hidupnya dijamin oleh Tuhan melalui sebuah tanda di dahinya sehingga dimanapun Kain pergi ia dikenali sebagai seorang pembunuh yang ditandai oleh Tuhan. Kitab Kejadian mencatat dialog antara Kain dan Allah.

Kata Kain kepada TUHAN: "Hukumanku itu lebih besar dari pada yang dapat kutanggung. Engkau menghalau aku sekarang dari tanah ini dan aku akan tersembunyi dari hadapan-Mu, seorang pelarian dan pengembara di bumi; maka barangsiapa yang akan bertemu dengan aku, tentulah akan membunuh aku." Firman TUHAN kepadanya: "Sekali-kali tidak! Barangsiapa yang membunuh Kain akan dibalaskan kepadanya tujuh kali lipat." Kemudian TUHAN menaruh

\footnotetext{
${ }^{14}$ Michael J. Osofsky, Albert Bandura, and Philip G. Zimbardo, "The Role of Moral Disengagement in the Execution Process," Law and Human Behavior 29, no. 4 (2005): 371-93, https://doi.org/10.1007/s10979-005-4930-1.

${ }^{15}$ Richard R.E. Kania, “The Ethics of the Death Penalty," The Justice Professional 12, no. 2 (2010): 145-57, https://doi.org/10.1080/1478601x.1999.9959538.

${ }^{16}$ United Nations, "Universal Declaration of Human Rights,” UN, accessed April 6, 2019, https://www.un.org/en/universal-declaration-human-rights/.
} 
tanda pada Kain, supaya ia jangan dibunuh oleh barangsiapapun yang bertemu dengan dia" (Kej. 4:13-15).

Hamilton menafsirkan bahwa tanda tersebut menjadi pembuangan dan pengasingan dari hadapan Allah. ${ }^{17}$ Hukuman Kain menjadi sangat berat ${ }^{18}$ di tengah komunitas masyarakat mula-mula yang masih dalam tahap awal pembentukan dan perkembangan.

Ketegasan untuk tidak boleh membunuh terlihat di dalam Sepuluh Perintah Allah (Keluaran 20:13). ${ }^{19}$ Perintah itu diturunkan langsung oleh Tuhan kepada bangsa Israel melalui Musa di Gunung Sinai. Owens memberikan keterangan bahwa dari sisi grammatical, kalimat tersebut merupakan sebuah perintah yang sama sekali tidak menyediakan opsi lain kecuali keharusan menaatinya. ${ }^{20}$ Hukum ini bukan sekedar aturan yang membatasi perilaku, tetapi menjadi sebuah dasar yang membentuk ideologikeagamaan tentang pentingnya manusia menghargai kehidupan. Merujuk pada pendapat Young, bahwa penilaian moral sangat dipengaruhi oleh ideologi agama dan politik. ${ }^{21}$ Dengan demikian, sebuah tindakan membunuh, merupakan pelanggaran berat terhadap prinsip ideologi-keagamaan dan tidak dibenarkan secara moral.

Permasalahannya, PL sendiri seperti terlihat tidak konsisten. Penuntut darah (revenge) memiliki legalitas untuk membalaskan dendam. Jika pembunuhan di balas dengan pembunuhan (oleh penuntut balas) maka seolah-olah PL memberikan ruang bagi pembunuhan balasan atas kejahatan yang sama. Deskripsi kota perlindungan sebagai tempat pelarian pelaku kejahatan dalam Kitab Bilangan, sudah cukup memberi gambaran tentang proteksi kehidupan pelaku kejahatan.

Keenam kota itu haruslah menjadi tempat perlindungan bagi orang Israel dan bagi orang asing dan pendatang di tengah-tengahmu, supaya setiap orang yang telah membunuh seseorang dengan tidak sengaja dapat melarikan diri ke sana. Tetapi jika ia membunuh orang itu dengan benda besi, sehingga orang itu mati, maka ia seorang pembunuh; pastilah pembunuh itu dibunuh. Dan jika ia membunuh orang itu dengan batu di tangan yang mungkin menyebabkan matinya seseorang, sehingga orang itu mati, maka ia seorang pembunuh; pastilah pembunuh itu dibunuh. Atau jika ia membunuh orang itu dengan benda kayu di tangan yang mungkin menyebabkan matinya seseorang, sehingga orang itu mati, maka ia seorang pembunuh; pastilah pembunuh itu dibunuh. Penuntut darahlah yang harus

\footnotetext{
${ }^{17}$ Victor P. Hamilton, Handbook on the Pentateuch (Grand Rapids, Michigan: Baker Academic, 2008), 59-60.

${ }^{18}$ Larry Ray, "Mark of Cain: Shame, Desire and Violence," European Journal of Social Theory 16, no. 3 (2013): 292-309, https://doi.org/10.1177/1368431013476536; R. W. L. Moberly, "The Mark Of Cain-Revealed At Last?," Harvard Theological Review 100, no. 01 (2007), https://doi.org/10.1017/s001781600700140x.

${ }^{19}$ Joseph P. Hester, The Ten Commandments: A Handbook of Religious, Legal and Social Issues (Jefferson. North Carolina: McFarland \& Company, Inc., Publishers, 2013), https://doi.org/10.5860/choice.40-6140.

${ }^{20}$ John Joseph Owens, Analytical Key to the Old Testament. Volume 1. (Grand Rapids, Michigan: Baker Books, 1998), 326.

${ }^{21}$ Olga Antonenko Young, Robb Willer, and Dacher Keltner, “"Thou Shalt Not Kill': Religious Fundamentalism, Conservatism, and Rule-Based Moral Processing," Psychology of Religion and Spirituality 5, no. 2 (2013): 110-15, https://doi.org/10.1037/a0032262.
} 
membunuh pembunuh itu; pada waktu bertemu dengan dia ia harus membunuh dia." (Bil. 35:16-19).

Selain itu, beberapa narasi di dalam PL juga menceritakan terjadinya pembunuhan yang disengaja sebagai tindakan hukumanan. Dalam kasus lembu emas misalnya, Musa yang barusan menerima sepuluh perintah Allah, memerintahkan Kaum Lewi untuk membasmi semua orang yang terlibat di dalam konspirasi tersebut.

Berkatalah ia kepada mereka: "Beginilah firman TUHAN, Allah Israel: Baiklah kamu masing-masing mengikatkan pedangnya pada pinggangnya dan berjalanlah kian ke mari melalui perkemahan itu dari pintu gerbang ke pintu gerbang, dan biarlah masing-masing membunuh saudaranya dan temannya dan tetangganya." Bani Lewi melakukan seperti yang dikatakan Musa dan pada hari itu tewaslah kira-kira tiga ribu orang dari bangsa itu (Keluaran 32:27-28).

Narasi tersebut membuktikan bahwa hukuman mati menjadi legal. Muncul persoalan serius. Membunuh seperti apa yang di larang di dalam PL dan hukuman mati seperti apa yang dilegalkan?

Analisis yang dibuat Hiers dapat dijadikan pegangan. ${ }^{22}$ Menurutnya, teks-teks Alkitab PL khususnya, penuh dengan ulasan yang dapat dibaca sebagai dukungan atau penolakan hukuman mati. Terdapat sejumlah teks yang eksplisit menyerukan, atau mendeskripsikan bagaimana hukuman mati diterapkan. Sementara itu, dibagian teks lainnya, terdapat rujukan untuk menentang hal tersebut. Lepas dari apakah hermenetik atas teks-teks tersebut dapat dipertanggung-jawabkan atau tidak, teks-teks PL pada akhirnya membagi dua kelompok di dalam menyikapi kasus ini, antara pendukung dan penentang hukuman mati. Geisler menyadari hal tersebut sehingga di dalam bukunya berjudul Etika Kristen (Christian Ethics), hanya mendeskripsikan argumentasi logis kelompok rekonstruksionisme dan retribusionisme serta penganut pandangan rehabilitasionisme tanpa menyatakan dukungannya pada salah satu aliran. Di dalam buku tersebut, Geisler hanya memaparkan analisisnya mengenai kelebihan dan kelemahan masing-masing kelompok secara Alkitabiah. Persoalan etis diserahkan kepada pembaca.

\section{Pengajaran Yesus}

Ajaran Yesus di dalam Perjanjian Baru (PB) dengan tegas menolak pembunuhan. Ironisnya, Yesus sendiri menjadi korban hukuman mati dari sebuah konspirasi pemuka agama Yahudi dengan pemerintahan Romawi. Pandangan Yesus terlihat sewaktu seorang perempuan dipergoki berzinah dan harus dihukum mati atas pelanggaran tersebut berdasarkan hukum Musa. Akan tetapi Yesus melepaskan perempuan itu dan berkata kepadanya, "Akupun tidak menghukum engkau. Pergilah, dan jangan berbuat dosa lagi mulai dari sekarang" (Yoh. 8:11). Kontrasnya adalah, ditengah desakan hukuman mati (death penalty by law), Yesus bertindak sebaliknya, mengampuni dan membebaskan.

\footnotetext{
${ }^{22}$ Richard H Hiers, "The Death Penalty and Due Process in Biblical Law," University of Detroit Mercy Law Review 81 (2003): 751-844.
} 
Pengutamaan pengampunan di atas hukuman adalah bagian dari misi Yesus di dalam dunia. PL identik dengan hukuman sedangkan PB mengedepankan pesan kasih dan pengampunan. Itu sebabnya, Yesus tidak pernah terlihat meniadakan preferensi di dalam PL tentang kesetaraan dan keadilan terhadap pelaku kejahatan. Yesus membawa hukum yang lebih tinggi dari preferensi tersebut. Narasi Matius 5:38-39 membuktikannya. "Kamu telah mendengar firman: Mata ganti mata dan gigi ganti gigi. Tetapi Aku berkata kepadamu: Janganlah kamu melawan orang yang berbuat jahat kepadamu, melainkan siapapun yang menampar pipi kananmu, berilah juga kepadanya pipi kirimu." Preferensi utama Yesus adalah pengampunan sedangkan orang-orang Farisi yang legalistik itu sulit menangkap maksudNya.

Balas dendam secara proporsional bukanlah solusi terbaik untuk memberikan hukuman setimpal. Justru Yesus menganjurkan sebaliknya, "Kamu telah mendengar firman: Kasihilah sesamamu manusia dan bencilah musuhmu. Tetapi Aku berkata kepadamu: Kasihilah musuhmu dan berdoalah bagi mereka yang menganiaya kamu" (Mat. 5:43-44). Dowd dan Malbon membuktikan bahwa Yesus sendiri telah ikut menjadi teladan konsep pengampunan melalui kematianNya di kayu Salib. ${ }^{23}$ Sehingga, hukuman mati sebagai sebuah aksi balas dendam, menjadi tidak relevan lagi dalam pandangan Yesus. Sebuah studi psikologi yang dilakukan oleh Sandoval menghantarnya pada kesimpulan bahwa pengampunan memiliki kemampuan untuk memulihkan jiwa dan menggeser ego, sehingga tercipta rekonsiliasi bagi diri sendiri dan orang lain. ${ }^{24}$

Hasil penelitian Brüne dkk juga membuktikan bahwa secara neurologis, tindakan mengampuni akan merangsang dan mempengaruhi wilayah DLPFC kanan serta membawanya ke tingkat paling rendah, sebuah wilayah yang berfungsi sebagai kontrol kognitif yang terlibat dalam menghambat respons emosional seseorang untuk balas dendam. ${ }^{25}$ Kekuatan inilah yang mendorong perkataan Yesus, "Ya Bapa, ampunilah mereka, sebab mereka tidak tahu apa yang mereka perbuat" (Luk. 23:34). Di tengah penderitaan tekanan serta perlakuan ketidakadilan, Yesus konsisten merepresentasikan perilaku kasih, yang berada di atas hukum 'mata ganti mata'. Jika demikian halnya, muncul pertanyaan, apakah tepat menjadikan frame ini sebagai landasan teologis untuk menolak hukuman mati? Sebab di pihak lain, terdapat asumsi-asumsi fundamentalisme agama yang justru mendorong terjadinya pelaksanaan hukuman mati bagi pelaku kejahatan. ${ }^{26}$ Sekilas terlihat ada unsur ambivalensi teologis, tetapi sebetulnya yang

\footnotetext{
${ }^{23}$ Sharyn Dowd and Elizabeth Struthers Malbon, "The Significance of Jesus' Death in Mark: Narrative Context and Authorial Audience,” Journal of Biblical Literature 125, no. 2 (2010): 271, https://doi.org/10.2307/27638361.

${ }^{24}$ Jennifer Monika Sandoval, "Forgiveness and the Soul: A Depth Psychological Perspective on Forgiveness," ProQuest Dissertations and Theses (2013).

${ }^{25}$ Martin Brüne, Georg Juckel, and Björn Enzi, “'An Eye for an Eye’? Neural Correlates of Retribution and Forgiveness," PLOS ONE 8, no. 8 (2013), https://doi.org/10.1371/journal.pone.0073519.

${ }^{26}$ James D. Unnever, Francis T. Cullen, and Brandon K. Applegate, "Turning the Other Cheek: Reassessing the Impact of Religion on Punitive Ideology,” Justice Quarterly 22, no. 3 (2005): 304-39, https://doi.org/10.1080/07418820500089091.
} 
terjadi di dalam lingkup religius adalah kehadiran dua pandangan ekstrim. Monica mengatakan, satu pandangan mewakili wajah Allah yang baik dan penuh pengampunan (kelompok ini menolak hukuman mati), dan pandangan lainnya mewakili wajah Allah yang keras, adil terhadap kejahatan dan menegakkan keadilan, sebagai kelompok yang pro hukuman mati. ${ }^{27}$ Setiap pandangan dibangun dengan argumentasi yang kuat dengan pendekatan hermenetik. ${ }^{28}$ Pada titik ini, problem hukuman mati menjadi tidak sesederhana dialektika pro-kontra.

Hukuman mati masih hadir sebagai sebuah tindakan hukum yang masih kontroversial. Terjadi tarik menarik pandangan antara tiga kekuatan yang paling berpengaruh, yakni hukum, hak asasi dan religiusitas. Sehingga akan selalu ada dua pandangan yang terus berhadapan, yang menganjurkan dan menolak pidana mati. Penganjur hukuman mati membangun argumentasi hukum, HAM dan teologis sama baiknya dengan para penentang hukuman mati.

Ada baiknya mempertimbangkan usulan Burgasson. Pidana mati tidak sesederhana dialektika: boleh-tidak atau pro-kontra. Terlibat banyak sistem yang rumit dan saling terkait dan membutuhkan pertimbangan yang sangat komprehensif. Berbagai kepentingan (termasuk politik, hukum dan moral) masuk ke dalam sistem ini dan saling berebut dominasi. Hal inilah yang menjadi alasan mengapa pendapat orang tentang hukuman mati dapat berubah menurut variabel situasi. Dikatakannya, perlu sebuah sketsa yang memasukkan karakteristik kontekstual tetapi relevan dari sebuah kasus kriminal yang diancam pidana mati. Sehingga, publik dan sistem hukum memiliki pertimbangan faktor moderat untuk setiap kasus yang bisa saja meringankan atau memperberat hukuman seseorang. ${ }^{29}$ Pendapat tersebut memberi ruang yang sangat cukup untuk menolak pandangan deterministik yang mengatakan bahwa manusia adalah hewan biologis dan sekedar mesin (robot) tanpa subjektifitas apapun. ${ }^{30}$ Binatang saja memiliki hak-hak hidup yang dilindungi oleh UU, terlebih manusia.

\section{Kesimpulan}

Membawa konsep pidana mati ke dalam dikotomi pro-kontra, tidak tepat. Pidana mati menyangkut hak hidup manusia. Itulah sebabnya, mengambil hak hidup itu secara resmi dari seseorang sebagai hukuman atas kejahatan yang dilakukannya (capital punishment) adalah dasar pertimbangan utama untuk mulai memikirkan alternatif

${ }^{27}$ Monica K. Miller and R. David Hayward, "Religious Characteristics and the Death Penalty," Law and Human Behavior, 2008, https://doi.org/10.1007/s10979-007-9090-z; Unnever, Cullen, and Applegate, "Turning the Other Cheek: Reassessing the Impact of Religion on Punitive Ideology."

${ }^{28}$ William Howard Whited, “'Eye for an Eye' or 'Turn the Other Cheek?' Exploring the Moderating Roles of Revenge and Forgiveness When Examining Death Penalty Support and Religious Fundamentalism" (The University of Southern Mississippi, 2016).

${ }^{29}$ Kyle A. Burgason and Lynn Pazzani, "The Death Penalty: A Multi-Level Analysis of Public Opinion," American Journal of Criminal Justice 39, no. 4 (2014): 818-38, https://doi.org/10.1007/s12103-014-9261-7.

${ }^{30}$ Kathleen D. Vohs and Jonathan W. Schooler, "The Value of Believing in Free Will: Encouraging a Belief in Determinism Increases Cheating," Psychological Science 19, no. 1 (2008): 49-54, https://doi.org/10.1111/j.1467-9280.2008.02045.x. 
proporsional. Perlu studi lebih lanjut, yang mungkin terkait dengan karakteristik kontekstual di setiap negara, budaya dan situasi politik, mengenai alternatif pengganti yang memang menghukum pelaku kriminal seberat-beratnya tetapi dengan tetap menghormati haknya untuk hidup.

\section{Referensi}

Amnesty International. "Death Penalty.” Amnesty International, 2017. https://www.amnesty.org/en/what-we-do/death-penalty/.

Brüne, Martin, Georg Juckel, and Björn Enzi. “"An Eye for an Eye'? Neural Correlates of Retribution and Forgiveness." PLOS ONE 8, no. 8 (2013). https://doi.org/10.1371/journal.pone.0073519.

Burgason, Kyle A., and Lynn Pazzani. "The Death Penalty: A Multi-Level Analysis of Public Opinion.” American Journal of Criminal Justice 39, no. 4 (2014): 818-38. https://doi.org/10.1007/s12103-014-9261-7.

Donatelli, Maria. "117 Countries Vote for a Global Moratorium on Executions." World Coalition Against the Death Penalty, 2014. http://www.worldcoalition.org/unitednations-resolution-moratorium-death-penalty-executions-general-assembly.html.

Dowd, Sharyn, and Elizabeth Struthers Malbon. "The Significance of Jesus' Death in Mark: Narrative Context and Authorial Audience." Journal of Biblical Literature 125, no. 2 (2010): 271. https://doi.org/10.2307/27638361.

Dylan Aprialdo Rachman. "Secara Global, Tren Eksekusi Mati Tahun 2017 Mengalami Penurunan Artikel Ini Telah Tayang Di Kompas.Com Dengan Judul 'Secara Global, Tren Eksekusi Mati Tahun 2017 Mengalami Penurunan', Https://Nasional.Kompas.Com/Read/2018/04/13/08033781/Secara-Global-Tre.” Kompas.com, 2018. https://nasional.kompas.com/read/2018/04/13/08033781/secara-global-treneksekusi-mati-tahun-2017-mengalami-penurunan.

Fleury-Steiner, Benjamin, and Ross Kleinstuber. "Death Penalty." In International Encyclopedia of the Social \& Behavioral Sciences: Second Edition, 2015. https://doi.org/10.1016/B978-0-08-097086-8.86020-1.

Geisler, Norman L. Etika Kristen: Pilihan Dan Isu [Christian Ethics: Options and Issues]. 5th ed. Malang: SAAT, 2007.

Halim, Devina. "5 Alasan Menolak Hukuman Mati Menurut Amnesty International Indonesia." Kompas.com, 2018. https://nasional.kompas.com/read/2018/10/10/23301511/5-alasan-menolakhukuman-mati-menurut-amnesty-international-indonesia.

Hamilton, Victor P. Handbook on the Pentateuch. Grand Rapids, Michigan: Baker Academic, 2008.

Hester, Joseph P. The Ten Commandments: A Handbook of Religious, Legal and Social Issues. Jefferson. North Carolina: McFarland \& Company, Inc., Publishers, 2013. https://doi.org/10.5860/choice.40-6140.

Hiers, Richard H. "The Death Penalty and Due Process in Biblical Law." University of Detroit Mercy Law Review 81 (2003): 751-844.

Insani, Fitri. "Upaya Indonesai Membebaskan Tenaga Kerja Indonesia Terpidana Hukuman Mati Di Arab Saudi." Jurnal Online Mahasiswa (JOM) Bidang Ilmu Sosial Dan Ilmu Politik 2, no. 1 (2014): 1-13. https://jom.unri.ac.id/index.php/JOMFSIP/article/view/3802/3693.

Kania, Richard R.E. "The Ethics of the Death Penalty." The Justice Professional 12, no. 2 (2010): 145-57. https://doi.org/10.1080/1478601x.1999.9959538. 
Lu, Hong, and Lening Zhang. "Death Penalty in China: The Law and the Practice." Journal of Criminal Justice, 2005. https://doi.org/10.1016/j.jcrimjus.2005.04.006.

Miller, Monica K., and R. David Hayward. "Religious Characteristics and the Death Penalty." Law and Human Behavior, 2008. https://doi.org/10.1007/s10979-0079090-z.

Moberly, R. W. L. "The Mark Of Cain-Revealed At Last?” Harvard Theological Review 100, no. 01 (2007). https://doi.org/10.1017/s001781600700140x.

Napitupulu, Erasmus A.T. "Gambaran Umum Penjatuhan Pidana Mati Di Indonesia." Institue for Criminal Justice Reform, 2015. http://hukumanmati.web.id/category/data/.

Osofsky, Michael J., Albert Bandura, and Philip G. Zimbardo. "The Role of Moral Disengagement in the Execution Process." Law and Human Behavior 29, no. 4 (2005): 371-93. https://doi.org/10.1007/s10979-005-4930-1.

Owens, John Joseph. Analytical Key to the Old Testament. Volume 1. Grand Rapids, Michigan: Baker Books, 1998.

Rachman, Adri Noor. "Hukuman Mati Di Indonesia (Death Penalty In Indonesia)." SSRN, 2014. https://doi.org/10.2139/ssrn.2407875.

Ray, Larry. "Mark of Cain: Shame, Desire and Violence." European Journal of Social Theory 16, no. 3 (2013): 292-309. https://doi.org/10.1177/1368431013476536.

Sandoval, Jennifer Monika. "Forgiveness and the Soul: A Depth Psychological Perspective on Forgiveness." ProQuest Dissertations and Theses, 2013.

Sumanto, Atet. "Kontradiksi Hukuman Mati Di Indonesia Dipandang Dari Aspek Hak Asasi Manusia, Agama Dan Para Ahli Hukum.” Perspektif 9, no. 3 (2004): 192215. http://jurnal-perspektif.org/index.php/perspektif/article/view/347.

Sutoyo, Daniel. "Tinjauan Teologis Terhadap Wacana Penerapan Hukuman Mati Bagi Pelaku Tindak Pidana Korupsi Di Indonesia.” DUNAMIS: Jurnal Teologi Dan Pendidikan Kristiani 3, no. 2 (2019): 171. https://doi.org/10.30648/dun.v3i2.195.

Tauhid, Akhmad Zainut. "Hukuman Mati Terhadap Pelaku Tindak Pidana Terorisme Perspektif Fikih Jinayah." IN RIGHT Jurnal Agama Dan Hak Azazi Manusia 1, no. 2 (2012): 368.

United Nations. "Universal Declaration of Human Rights." UN. Accessed April 6, 2019. https://www.un.org/en/universal-declaration-human-rights/.

Unnever, James D., Francis T. Cullen, and Brandon K. Applegate. "Turning the Other Cheek: Reassessing the Impact of Religion on Punitive Ideology." Justice Quarterly 22, no. 3 (2005): 304-39. https://doi.org/10.1080/07418820500089091.

Vohs, Kathleen D., and Jonathan W. Schooler. "The Value of Believing in Free Will: Encouraging a Belief in Determinism Increases Cheating." Psychological Science 19, no. 1 (2008): 49-54. https://doi.org/10.1111/j.1467-9280.2008.02045.x.

Whited, William Howard. “'Eye for an Eye' or 'Turn the Other Cheek?' Exploring the Moderating Roles of Revenge and Forgiveness When Examining Death Penalty Support and Religious Fundamentalism." The University of Southern Mississippi, 2016.

Young, Olga Antonenko, Robb Willer, and Dacher Keltner. "'Thou Shalt Not Kill': Religious Fundamentalism, Conservatism, and Rule-Based Moral Processing." Psychology of Religion and Spirituality 5, no. 2 (2013): 110-15. https://doi.org/10.1037/a0032262. 